\author{
Ж. Әбдіғаппарова \\ Назарбаев университеті, Қазақстан, Нұр-Сұлтан қ., \\ e-mail: zhabdigapar@nu.edu.kz

\section{ҚАЗАҚ ӘАЕБИЕТІНАЕГІ ШЫНҒЫС ХАН БЕЙНЕСІ}

Шыңғыс хан Екінші мыңжы^дықта бүкіл Еуразияны өз билігімен жаңа арнаға бұрған тарихи тұлға. Мақалада автор Шыңғыс ханның әдеби көркем бейнесіне талдау жасауды мақсат етеді.

Талдау алгоритмі: Шыңғыс хан жайлы тек қазақ әдебиетінде ғана емес, соңғы үш ғасырда Батыс пен Шығыста көркем шығармалар жазылды. Қазақ әдебиетінде әр жылдарда жарық көрген Шыңғыс хан өмірінің әр кезеңіне арналған шығармаларды назарға ала отырып, қаған бейнесінің сомдалу ерекшелігіне тоқталады. Сондай-ақ, XX ғасыр басында жазылған, бізге қолжазба күйінде жеткен ақын Шәді Шәңгірұлының «Тарихнама» дастанындағы Шыңғыс хан бейнесінің сомдалу ерекшелігіне талдау жүргізеді. Тарихи шығарма - тарихтың өзі емес, көркемделіп берілген түрі. Тарихи тұлға да, дәуір де мүлде басқа бір кейіпте көрінуі мүмкін. Аегенмен қаламгер өзі өмір сүрген замандағы тарихи ұғым, әлеуметтік танымнан ұзап кете алмайды. Мақала авторы әр кезеңдегі жазылған Шыңғыс хан туралы көркем туындыларды осы тұрғыдан сараптайды.

Ерекшелігі. «Тарихнама» дастанында Шыңғыс ханның бүкіл өмірі қамтылады. Шәді ақын өзі де Шыңғыс ұрпағынан болғандықтан дастанда келтірген мәліметтерге сол кездегі тарихи шежірелерден сілтеме де беріп отырады. Аастанда жырланатын Шыңғыс ханның жасаған жорықтарының көркемдік шындығын тарихи деректерге сүйене отырып, тарихи шындықпен байланысын салыстыра отырып талдау жасайды. Соның ішінде Отырарға жасаған жорығына аса назар аударылады. Шыңғыс ханның тұлғалық бейнесін жан-жақты ашуға талпынады. Сондайақ, мақала авторы дастанда кездесетін Шыңғыс ханның өміріне, жеке басына қатысты қызықты мәліметтерді сараптай отырып, өзіндік тұжырым жасайды.

Түйін сөздер: қазақ әдебиеті, Шыңғыс хан, тарихи тұлға, әдеби бейне, дастан.

$$
\begin{gathered}
\text { Zh. Abdigapbarova } \\
\text { Nazarbayev University, Kazakhstan, Nur-Sultan, } \\
\text { e-mail: zhabdigapar@nu.edu.kz }
\end{gathered}
$$

\title{
The Image of Genghis Khan in Kazakh Literature
}

In the second millennium, a historical figure Genghis Khan has transformed all of Eurasia by his power. In this article the author aims to analyze literary artistic image of Genghis Khan.

Algorithm of analysis: In the last three centuries, literary works about Genghis khan were written not only in Kazakh literature, but also in the West and East. This work discusses the specific features of kaghanimage by using Kazakh literary works, published at different time periods and devoted to Genghis Khan's life stages. Moreover, it analyzes the way Genghis Khan is featured in a poet Shadi Shangiruly's epos "Tarihname", a manuscript written in the early 20th century. Historical work is not a history itself, but its embellished form. Both of historical figure and epoch might be given in completely differentguise. However, the writer can not go far from the historical concept and social comprehension of the era he has lived. The author of this article analyzes this side of the literary works about Genghis Khan written in each period.

Specification. The poem "Tarihname» includes the whole life of Genghis khan. Since Shadi himself was a descendant of Genghis Khan, for each information in the epos he gives the citations to historical chronicles of that time. The author of this article makes analysis of the interesting information in the epos about Genghis Khan's life, and compares itto the historical facts. Particular attention is paid to Genghis khan'sinvasion of Otrar. The author tries to reveal the personality of Genghis Khan in detail. Also, after analyzing interesting facts about Genghis khan's life and personality, he makeshis individual inferences.

Key word: Kazakh literature, Genghis Khan, historical figure, literary image, epos. 


\title{
Ж. Абдигапбарова \\ Назарбаев университет, Казахстан, г. Нур-Султан, e-mail: zhabdigapar@nu.edu.kz \\ Образ Чингисхана в казахской митературе
}

\begin{abstract}
Чингис хан - историческая личность, своим правлением во Втором тысячелетии повернувшая в новое русло всю Евразию. В настоящей статье автор ставит своей целью анализ литературнохудожественного образа Чингис хана.

Алгоритм анализа: За последние три столетия о Чингис хане написаны художественные произведения не только в казахской митературе, но и на Западе и Востоке. В изданных в разное время произведениях казахской митературы, посвященных различным периодам жизни Чингисхана, внимание акцентируется на особенностях изображения образа кагана. Также в дастане акына Шади Жангирулы «Тарихнама», написанном в начале XX века и дошедшем до нас в рукописном виде, проводится анализ особенностей создания образа Чингис хана. Историческое произведение - это не сама история, это ее живописная версия. И историческая кичность, и эпоха могут быть представлены в совершенно другом образе или виде. И все же писатель не может отстраниться от исторического восприятия и социального познания времени, в котором жил он сам. Автор статьи анализирует художественные произведения разного периода о Чингис хане с этой точки зрения.

Отличительные особенности. В Аастане «Тарихнама» охвачена вся жизнь Чингис хана. Поскольку Шади акын и сам является потомком Чингис хана, в сведениях, которые приводятся в дастане, он ссылается и на исторические летописи того времени. Проведен сравнительный анализ художественной достоверности воспеваемых в дастане нашествий, совершенных Чингис ханом, с исторической правдой с опорой на исторические данные. Особое внимание в том числе уделяется набегу на Отрар. Автор стремится всесторонне раскрыть мичностный образ Чингис хана. Также автор статьи после глубокого изучения интересных сведений, имеющих отношение к жизни Чингис хана и его персоне, приходит к собственным выводам.
\end{abstract}

Ключевые слова: казахская митература, Чингис хан, историческая мичность, митературный образ, Аастан.

\section{Kipicпe}

Бір ұлттың әдебиеті дегеніміз - сол ұлттың биік рухы. Тілі, сөз өнері, көркем әдебиеті сақталса ғана сол ұлттың сақталып қалатынын көзі ашық адамның бәрі біледі. XX ғасыр басында алаш арысы Жүсіпбек Аймауытов «Әдебиет - ұлттың жаны. Ұлттық сана, тағдыр, жан жүйесі - көркемөнердің басты тақырыбы» деп бекер айтпады.Көнермейтін осы бір даналық тәлімде ұлттың ұлылығын түсіну үшін әдебиеттің көтеретін жүгі ауыр деген салмақты да саналы ұғым жатыр.Сондықтан да болар рухын сақтауды мұрат тұтқан халық «тақыр жерден тамырын тіміскілеп жүріп» әдебиетін жасады.

Біздің мақаламызға арқау болатын мәселе, Шыңғыс ханның әдеби бейнесі. Қаламгер емес, ғалым емес, әдеби қайраткер де емес. Ұлы қаған. Екінші мыңжылдықта бүкіл Еуразияны өз билігімен, өз күшімен жаңа арнаға бұрған алып тұлға. 1996 жылы Бүкіләлемдік ақпарат орталығы Америкада шығатын әйгілі "Вашингтон пост" басылымы жүргізген сауалнама негізінде Шыңғыс ханды екінші мың жылдықтың ең басты тұлғасы деп жариялаған.
Шыңғыс хан мен қазақ әдебиетінің арасында байланыс бар ма, болса қандай сабақтастық болуы мүмкін? Шыңғыс хан жайлы тек қазақ әдебиетінде ғана емес, соңғы үш ғасырда Батыс пен Шығыста жазылған шығармалар да жеткілікті. Өзіміз білетін Исай Калашниковтің «Жестокий век» романынан бастап соңғы жылдары жарық көрген американ жазушысы Памела Сардженттің «The Ruler of the Sky. A novel of Genghis Khan», (Повелитель вселенной. Роман о Чингисхане), Алексей Гатаповтың «Тэмуджин» атты романдары бұл сөзіміздің дәлелі. Әрине, тарихи шығарма - тарихтың өзі емес, көркемделіп берілген түрі. Тарихи тұлға да, дәуір де мүлде басқа бір кейіпте көрінуі мүмкін. Дегенмен қаламгер өзі өмір сүрген замандағы тарихи ұғым, әлеуметтік танымнан ұзап кете алмайды.

Қай халықтың әдебиеті немесе мәдениетін алсақ та тарихпен тікелей сабақтастықта дамитынына көз жеткіземіз. Ғылымдағы қай сала болмасын ол тарихпен тығыз байланысты, тарихтан тыс тіршілігі жоқ. Соның ішінде әдебиет. Қай дәуірде жазылмасын, сол кезеңнің, өзі өмір кешкен қоғамның тарихи оқиғалары мен құбылыстарына негізделеді. Бүгінгі қаламгер өткен тарихи оқиғаларды өз туындысына арқау 
етсе де, ол негізінен бүгіннің жемісі. Өзі өмір сүріп отырған кезеңнен әлдеқайда ерте кезеңді тілге тиек етсе де, ол бүгінгі күннің көзқарасымен пайымдайды. Өткен күннің ескісін жаңартып, оқырманға бейтаныс боп келген тағы бір қырын, бір ақиқатын бүгінгі пікірмен жаңаша қырынан танытуға тырысады. Бұдан шығар қорытынды тамырын тереңге жайған тарих ешқашан сөнбейді де, ұмытылмайды.

Осыны ескерсек, Шыңғыс хан сияқты тұлғаның бейнесі әдебиеттен көрініс табуы заңдылық.

\section{Тәжірибе}

Тарихи дамудың жаңа арнасын салып кеткен ұлы қаған Шыңғыс хан жайлы әдеби туындылар сол заманда-ақ, өзінің көзі тірісінде де туғаны айқын. Өйткені, билеушілеріне Мадақ жыр арнау дәстүрі ежелден болған. Одан беріде, Шыңғыс хан өмірден өткеннен кейінгі туған шығармалар. Ауыз әдебиеті арқылы ықылым заманнан бүгінге жеткен қағантуралы қаншама аңыз, әңгіме, өлеңжырлар бар. «Халықтың жадынан артық қазына жоқ» деп түйсінген қазақ халқы үшін ел аузында сақталып келе жатқан аңыз, әңгімелер ұрпақтанұрпаққа әр дәуірде жаңа форма тауып, ауысып отырған. Халық өзі құрмет тұтқан, әрі ерлігіне сүйсінген адам туралы әр кезеңде сол қоғамда қалыптасқан сана тұрғысынан жаңа шығармалар жазып отырған. Әрине бір қоғамда тек қана бір көзқарас қалыптасу мүмкін емес. Сондықтан тарихи оқиғаға, тарихи тұлғаға әртүрлі баға беріліп жатуы да әбден мүмкін. Біздің мақаламызға арқау болып отырған Шыңғыс хан феномені де солай. Қазақ әдебиетіндегі Шыңғыс хан бейнесі де бірдей емес. Шыңғыс хан туралы жазылып та, айтылып та жүр. Соңғы жылдарда әдеби бейнесін негіздеген ғылыми мақалалар да жазылып жүр. Бірақ бұл тақырып әлі де тереңдей зерттеуді қажет етеді. Кез келген тарихи тұлға туралы зерттеу жүргізгенде обьективті көзқарас болуы керек. Ол тұлға қалай болғанда да тарихта орны бар. Елбасымыз өзінің «Ұлы даланың жеті қыры» атты мақаласында «Бүгінде төл тарихымызға оң көзқарас керек. Бірақ, қандай да бір тарихи оқиғаны таңдамалы және конъюнктуралық тұрғыдан ғана сипаттаумен шектелуге болмайды. Ақ пен қара - бір-бірінен ажырамайтын ұғымдар. Бұлар өзара бірлескенде жеке адамдардың да, тұтас халықтардың да өміріне қайталанбас реңк береді» - (Назарбаев, 21.11.2018) деген пікірі біздің ойымызды нақтылай түседі.
Қазақ ауыз әдебиеті арқылы бүгінге жеткен аңыз-әңгімелер мен жыр-дастандардан бөлек әр жылдарда жазылған көркем шығармаларда жазылды. Мысалы, Әбіш Кекілбаевтың Шыңғыс ханның өмірінің соңғы күндері мен өлімі жайлы халық аузында ежелден сақталып келе жатқан аңыз-әңгімелер негізінде жазылған «Ханшадария хикаясы» атты хикаяты, Тұрсынхан Зәкенұлының Шыңғыс дәуіріндегі Керей, Найман мемлекеттерінің жеңілісі жайындағы «Көк бөрілердің көз жасы» атты тарихи романы, Мұхтар Шахановтың Шыңғыс ханның Отырар қаласын алуы туралы жазылған «Жеңілген жеңімпаз хақындағы Отырар дастаны немесе Шыңғыс ханның қателігі» атты поэмасы, Мұхтар Мағауиннің «Шыңғыс хан және оның заманы» деректі тарихи хикаясы кітабы т.б. Қарап отырсақ, әр алуан көзқарасты ұстанған бұл шығармалар қазақ әдебиетінің алтын қорынан ойып тұрып орын алатын құнды мұралар десек қателеспейміз. Бұл шығармаларда қаған бейнесі әр қырынан көрінеді. Сондай-ақ, жоғарыда аталған үш шығарма қаған өмірінің белгілі бір кезеңдеріне арналған. Әр шығармада авторлардың тарихи тұлғаны сомдаудағы өзіндік ұстанымы көрініс табады.

\section{Нәтижелер мен талқылаулар}

Біздің бүгінгі мақаламызға арқау болатын шығармамыз XX ғасырдың басында ғұмыр кешкен ақын Шәді Жәңгірұлының қаламынан туған Шыңғыс ханның толық өмірін суреттейтін «Тарихнама» атты дастаны. Бұл шығарманың ерекшелігі тұтас моңғол халқының тарихын баяндаумен қатар Шыңғыс қағанның толық өмірінен сыр шертеді.«...Қазақ эпосынан басталып тарихи шығармаларымызға ұласқан, сонан соң жазба әдебиетімізге көшкен осы көркемдік арна-күллі қазақ әдебиетінің ішкі рухани тұтастығын ұстап тұрған басты құндылығымыз»,- деп жазады белгілі ғалым, профессор Қансейіт Әбдезұлы (Әбдезұлы, 2004:16). Осындай халқымыздың рухани құндылығы болып саналатын шығарманың бірі Шәді төренің «Тарихнама» дастаны деуге болады.

Бірнеше дәуірді суреттейтін Шәдінің «Тарихнама» дастаны екі үлкен тараудан тұрады. Бірінші тарау «Шыңғыс хан» тарихы деп аталса, екінші тарау «Абылай хан» тарихына арналады. Ақынның бұл шығармасы жеке кітап болып басылмаған, бізге автордың өз қолжазбасы күйінде жеткен. Дастанның жазылған уақыты көрсетілмеген. 1914 жылы Ташкентте басылған 
«Хикаят халифа һарон-ар Рашид» деген кітабының соңында Шәді баспаға әзірлеп қойған шығармаларының тізімін берген. Сол тізімнің ішінде «Тарихнама» поэмасы да бар.

Бүгінде бұл қолжазба Алматы қаласындағы M. Әуезов атындағы Әдебиет және өнер институтының қолжазба қорында сақтаулы. Қолжазбаны институтқа ауыз әдебиеті үлгілерін мұқият жинаушы, қарт мұғалім Минат Қалдыбаев әкеп тапсырған. Минат Қалдыбаев Шәдінің шығармаларынан өзі көшірген екі қолжазба және Шәдінің бір қолжазбасын табыстаған.

Бұл шығарманың кітап болып басылып шықпағанына Кеңес кезеңіндегі саясат салқынының әсер ықпалы болуы да мүмкін. Өйткені Шәді ақынның көзі тірісінде көптеген шығармалары баспа жүзін көрген еді.

Ақынның бұл шығарманы жазарда қандай дерекке сүйенгені жайлы Шәдітанушы Немат Келімбетов былай дейді: «Мазмұнына, құрылысына қарағанда Шәді бұл дастанын Абулғазы Бахадурханның «Шежіре-й түрік» деген кітабының ықпалымен, соған еліктеп жазған сияқты. Сондай-ақ «Тарих-наманы» оқи отырып, Мұхаммед Юсуфтың «Тарихи Муқимханий» (XVIII ғ), алғашқы нұсқасын Нуриддин Ахунд Мулла Тархад Самарқанди жазған «Тарихи Рақимий», Мунис Хоразимий мен оның жиені Мухаммадриза Агахий жазған «Фирдавс-уа-иқбал» сияқты күрделі тарихи еңбектермен Ш. Жәңгіровтың жақсы таныс болғанын аңғару қиын емес» (Келімбетов, 1974:56).

Шыңғыс ханның өмірі мен ерлік істері баяндалатын «Тарихнама» дастанын жеке-дара қарастырудың мәні зор. Өйткені бұл шығарманың ақын шығармашылығы тұрғысынан қарағанда да, XX ғасыр басындағы қазақ әдебиеті тұрғысынан қарағанда да өзгешелігі мол. «Тарихнама» Шәдінің өзге туындыларының және өз дәуіріндегі шығармалардан тақырыптық және көркемдік жағынан ерекшеленеді. Шәді - көп жазған ақын. Әрі оның жазған шығармаларының басым бөлігі өзінің көзі тірісінде Орынбор, Қазан, Ташкент қалаларында жарық көріп отырған. Шәді дүниесін көп зерттеген ғалым Немат Келімбетов: «Оның жүз мың жолдай өлеңжыр жазып, соның жетпіс бес мыңдай жолының ақынның көзі тірісінде түрлі қалаларда басылып шыққан», - дейді Келімбетов(Келімбетов, 1974:86).

Ақынныңбаспакөргенбірқатаркітаптарымен әлі жарыққа шықпаған шығармалары Қазақстан Республикасы академиясының орталық ғылыми кітапханасы мен М.О. Әуезов атындағы әдебиет және өнер институтының қолжазбалар қорында сақтаулы. Сондай қолжазбалардың бірінде Шәді төре Жәңгірұлының баспадан шыққан кітаптары мен баспаға берілген қолжазбаларының тізімі берілген. Баспадан шыққан еңбектерінің қатарында «Назым Сияр Шәриф», «Назым Чаһар дәруіш», «Шайхы Барсиса», «Беташар», «Қамарзаман», «Атымтай» сияқты жалпы саны он үш кітаптың аты көрсетілсе, «Хәзірет Ескендір», «Тарихнама», «Ибраһим Халиулла», «Мұса Перғауын хикаясы», «Әһуал қиямет» тәрізді тоғыз шығарманың баспаға берілгені айтылады(Әдебиет және өнер институты Қолжазба қоры. 888 бума. 1 - дәптер).

Шәді ақынның көптеген шығармалары діни тақырыпқа арналған. Ал тарихи тақырыпқа арнаған шығармасы осы «Тарихнама» дастаны. Дастанның тілі көне түркі яғни шағатай тіліне жақын. Ақын шығармаларының мұндай тілдік ерекшелігінің оқырманға қатысты болғанына профессор Немат Келімбетов те назар аударған болатын. «...Шәді өз шығармаларын жазғанда оны оқитын адамдардың көбірек болу жағын да сөзсіз есепке алды. Өйткені сауатты, түрлі медреселерде оқып білім алған адамдар қазақ даласынан гөрі, Орта Азияда көп болатын. Солардың бәріне азды-көпті түсінікті тілде жазу - кітаптарды көп тиражбен бастырып шығаруға мүмкіндік беретін болған, әрі ақынның атағын арттыра түсуге ықпал еткен»- дейді (Келімбетов, 1974: 81). Ғалым Шәді шығармаларының өзбекшеге бейімделген шағатай тілінде жазуының ең нанымды себебін дәл көрсеткен. Сондықтан шығарма ішінде түрік, араб, парсы сөздері жиі кездеседі. Өйткені Шәді ақын мұсылманша білім алғанын, діни сауатты болғанын, Шығыстың классикалық поэзиясымен сусындап өскенін жоғарыда айттық. Осы «Тарихнама» дастанында да Шығыстық поэзияның ықпалы байқалады. Шығыстың классикалық әдебиетінде шығарманың кіріспесі Жаратушы Құдайға мадақ айтумен басталады. Шәді осы заңдылықты «Тарихнама» дастанында да сақтаған.

Айтылған имандардан кітаптар көп, Бәрінің басында бар бисмилласы, -

деп бастайды сөздің басын Шәді шайыр.

Ақынның өзі төрелер тұқымынан болғандықтан дастанда былай дейді:

...hәм өзім хан әулеті болған үшін,

Айтпаққа көңілім кетті қылған ісін. 
Мойнына баласының ләзім болар,

Істемек атасының әр жұмысын

(Жәңгірұлы, Қолжазба қоры: 31).

Бабаларының шежіре - тарихын жырлаған Шәді ақынның осындай батыл қадамға барып, хандардың тарихын жырға қосуы, оның шынайы таланттылығынан, өткенге деген жанашыр, қамқорлығынан болса керек.

Көпшілік жұртқа түсінікті болу үшін айта кетейік, «Төре - қазақ қоғамындағы әлеуметтік топ. Шыңғыс ханның ұрпақтары төре саналған. Олар қазақ руларына қосылмайтын өз алдына дербес қауым болып саналған. Төрелер өздерін “ақсүйек” қатарына жатқызған. Хандар тек төрелер арасынан сайланды» («Қазақстан»: Ұлттық энциклопедия, 1998: 125).

«Тарих-намада» өзіндік бастауы мен аяқталуы бар оқиғалық кешендер бір-біріне тәуелсіз түрде, қатар өрнектеледі. Бірақ олар уақыттық ретпен берілген. Мұндай сюжет «хроникалды» деп аталады. Әр тарауда жеке-жеке оқиғалар баяндалады.

Дастан - «Ұлт халықтардың шығуы туралы», «Мағұлдардан хандықтың кетіп, Аркікүн тауына қашып барғаны», «Барша рулардың шыққандығы жайлы», «Қазақтың Үш жүзге бөлінуі», «Мағұл хандарының тарихы», «Шыңғыс ханның дүниеге келген тарихы», «Тамужиннің Керейт тайпасын Оң ханмен ұрысы», «Тамужиннің Оң ханға елші жібергені», «Тамужиннің хан болғаны», «Шыңғыс ханның наймандармен ұрысып жеңгені», «Жамұқаның өлгені», «Шыңғыстың Маркат елін алғаны», «Шыңғыс ханның қырғыздармен ел болғаны», «Күшлік пен Тоқта бегі артынан барғаны», «Шыңғыс ханның Қытай, Қарқытай шүршіттерді жеңгені», «Шыңғыс ханның қатындары мен балаларының есебі», «Шыңғыс ханның Мұһамадилуажды Сұлтан Мұһаммад Хорезмге елші қылыпжібергені», «Сұлтан Мұһаммадтың дәулетінің қайтқан себебі», «Шыңғыс ханның Бұхараға аттанғаны», «Үгдай хаһан, Шағатай ұрысып Отырарды алғаны», «Жошы ханның Жанд барғаны», «Алақ ноян Сақтабұқамен Панакент (Панжакент) және Хожантқа келгені», «Шыңғыс ханның Тахшаб, Терміз, Балх барғаны», «Шыңғыс ханның Сұлтан Мұһаммадтың артынан әскер жібергені», «Шыңғыс ханның Сұлтан Жалаладдинмен ұрысқаны», «Шыңғыс ханның Толы ұғлын Хорасанға жібергені», «Толы ханның Нашабурға барғаны», «Шыңғыс ханның өз жұртына (еліне) қайтқаны», «Шыңғыстың мінезпейілдері», «Шыңғыс хан ұғлы Үгдай хаһанның хан болғаны» деген сияқты тарауларға құрылған. «Тарихнаманың» композициялық құрылымы да өзгеше. Мұны монтаждық композицияға жатқызуға болады. Мұндағы оқиғалық бөліктердің көбінің өзара себеп-салдарлық байланысы жоқ. Өзіндік дербестігі бар оқиғаларды бейнелеп, оларды монтаждық тәсілмен құрастыру арқылы автор бірнеше дәуір шындығын барынша мол қамтып бере алған.

Шәді поэманың «қазақтың үш жүзге бөлінгені» деген тарауында:

Ілгері рулардың хикаяты,

Шығарған Абулғазы тарих хаты, -

(Жәңгірұлы, Қолжазба қоры: 43).

деп, Абулғазының тарихымен таныс екенін аңғартады.Сондай-ақ ақын поэма ішінде аты белгісіз «Рузата Сафа» деген кітапқа да сілтеме жасайды. Бұдан ақынның осы еңбекті жазарда біраз кітапты қарап шыққанын байқауымызға болады.

Дастанда қазақ халқының үш жүзге қалай бөлінгені жайлы айтылады.

\footnotetext{
Жазылған нұсқаларын көріп түрін,

Айтуға мүмкін болмай бәрін мұның,

Үш жүзге қазақ халқы айрылуда,

Ыңғайлы білдірейін мен де бірін.

Жошы хан-Шыңғыс ханның үлкен ұлы,

Тұқымы қазақтарға хандық қылды.

Жошының хандық еткен әулетінен

Біріне Аланша деп ат қойылды.

Уақытында Аланшаның қазақ елі,

Алатау-Сарыарқада жүруші еді.
}

Әр жүз бозқасқадан мал сойып, ортаға бауыр қойып серттеседі. Аланша хан бәріне ортақ болғандықтан, ұрандары «Алаш» болып айтылды. Кейінірек бүкіл қазақтың елі «Алаштың баласы» деп аталды.

«Мағұл хандарының тарихы» деген тарауында Шәді ақын моңғол халқының тарихынан, оларды басқарған хандар тарихынан сыр шертеді.

Ал Шыңғысхан атақты Буденжырдың тікелей ұрпағы болып табылады.

Шыңғыс хан мәужуд болып дүние енді,

Оныншы Буденжырдың баласы еді.

Сол үшін халық аузында нақыл болып,

Сағымнан пайда болған Шыңғыс деді.

(Жәңгірұлы, Қолжазба қоры: 70).

Ақын өз шығармасында тарихи деректермен қатар, ел арасына кеңінен тараған аңыздарды 
да орынды пайдалана білген. Шыңғыс ханның дүниеге келуі жайын ақын былай суреттейді:

\footnotetext{
Тамужин анасынан дүниеге енді, Бір қолдың алақаны жұмулы еді. Қатындар қызмет еткен қарағанда, Ішінде ұйып қалған бір қан көрді Көргендер тәһсін етіп қайран қалып, Даналар бұл сөзді айтты аузына алып. Бұл бала патша болып заманында, Адамнан қан төгілер судай ағып.
}

Шыңғыстың дүниеге қолына қан ұстап келгенінен-ақ, оның әлемді жаулайтынынан хабар береді.

Айтқаны даналардың болды дұрыс, Өмірінің барлығында қылды ұрыс.

Адамды қатал етіп қойдай қырып,

Уақытында неше түрлі болды жұмыс, -

деп жырлайды ақын (Жәңгірұлы, Қолжазба қоры: 71).

«Моңғолдың құпия шежіресінде»: «Сол кезде Есукей батыр татардың Темужін-үкі, Қорибұқа деген адамдарын ұстап әкелгенде, екіқабат Уәлін-үжіннен Онынның Делуін Бұлтық деген жерінде Шыңғыс қаған туады. Шыңғыс қаған туғанда, оң қолымен асықтай қан шеңгелдей туылыпты. Татардың Темужін - үкісін ұстап әкелген кезде туды деп ырымдап, атын Темужін қойыпты» (Моңғолдың құпия шежіресі, 2009: 34).Бұл пікірді ғалым Э.Хара-Даван өзінің «Чингис-хан как полководец и его наследие» атты еңбегінде моңғол-қытай жылнамасы Юаньши (Сокровенное сказание) еңбегіне сілтеме жасай отырып, растайды. «Исугей-богатуром был предпринят поход против племен та-та-эр (китайская транскрипция слова татар) причем взят в плен глава этого племени Те-му-чэн. Одновременно его жена родила «императора» (так называет летопись Чингис-хана во все периоды его жизни). У него в руке оказался крепко зажатым ком крови, подобный красному камню. В память одержанного успеха (совпавшего с днем его появления на свет) родившийся ребенок был назван именем взятого в плен Те-мучэна. (Хара-Даван, 1991: 23-24). Шәді ақын да ортағасырдағы тарихи еңбектерден таныс болғаны анық.

Шәді ақын дастанның «Тамужиннің хан болғаны» атты тарауында:

Өзінің заманында ұрысқанмен

Тең бола білмес деді ешкім оған.

Аздан соң Тамужиндік аты қалып,

Шыңғыс деп атап кетті барша халық .
Шәді ақын Темужинді халқы хан көтергенін, Шыңғыс хан деген ат бергенін осылай баяндайды.

Ал басты тарихи дереккөзі болып табылатын «Моңғолдың құпия шежіресі» еңбегінде 123үзік: Алдан, Құзар, Сәжібек бірқаншасы алдын ала ақылдасып алып, Темежәнге келіп:

Сені Қаған сайлаймыз, - десті.Егер, сен Қаған болсаң, қалың жауыңа алғыншы болып шабар едік. Олардың Қара-Ордасын, қарайған қарашысын, қас сұлу қатұнын, қас жүйрік қазанатын олжалап құзырыңа қаратар едік. Егер, сен Қаған болсаң, қалың аңды абалап, ұтылап алдыңа әкелер едік.Қиырсыз қырдың кигін келелеп әкелер едік. Құла дүздің құланын құралап әкелер едік. Жаугершілікте бұйрығыңнан бас тартсақ, бейбіт күнде ісіңді ластасақ, қатынбала, мал-мүлкімізден айырып, қара басымызды елсіз иенге жер аударып жібер. Осындай сертпен Темежәнді Қаған көтерді. Шыңғыс-Қаған деген ұлық мәртебе берді», - деп жазылған (Әбенайұлы, 2016: 493).

Бұл деректі ғалым Э.Хара-Даванның «Чингис-хан как полководец и его наследие» атты еңбегінен де кездестіреміз.Қарап отырсақ, Шәдінің «Тарихнама» дастаны тарихи деректі шығарма. Ақын дастанда келтірілген әрбір тарихи маңызы зор оқиғалардынақты деректерге сүйеніп отырып жазғаны анық көрініп тұр.Осы жерде әлемдегі әйгілі аттардың біріне айналған «Шыңғыс» деген қандай ұғымды білдіреді деген ой қызықтыратыны да рас. Шыңғыс хан туралы қаншама зерттеулер жасалғанымен «Шыңғыс» сөзінің этимологиясы туралы әлі күнге дейін анықталған жоқ. Алайда осы ұғымның астарына үңілген біршама пікірлерді келтіре кеткеніміз де жөн болар.

Э. Хара-Даван «Шыңғыс» сөзінің этимологиясы туралыбылай деп жазған: «Мы нигде не встречаем удовлетворительного объяснения названия «Чингис». На языке западных монголов, ойратов, калмыков в буквальном значении это слова значит «крепкий», «сильный». Но эти определения довольно отнести не столько понятно физическому, как духовному; К уму, характеру и т.п.» дейді. (Хара Даван, 1991: 33). Ғалым өзінің бұл пікірін XX ғасырдың бас кезінде жазған болатын. Келтірілген «мықты», «күшті» деген сөздер тек моңғол, қалмақ тілдерінде ғана емес, түркі тілінде бар. Зерттеушілердің пікірінше ұйғыр тілінде де «Чиң» сөзі «мықты, бекем, күшті» деген мәнді білдіреді. Бірақ бұл мағынадағы сөздер адамның мінез-құлқына, қасиеттеріне байланысты айтылса керек. Ал біз айтып отырған «Шыңғыс» - сөзі Қағанға беріліп 
отырған лауазым яғни титул. Мұны шатастырмауымыз керек.

Белгілі тарихшы ғалым Джон Мэн осы мәселе жайында өзінің «Шыңғыс ханның көшбасшылық құпиясы» атты еңбегінде: «Ғалымдар бұл атақтың түп негізі жөнінде күні бүгінге дейін пікір таластыруда. Түркінің немесе қытайдың бірде-бір патшалық атағы оған тең келмес еді, өйткені бірде-бір әмірші бұрын-соңды мұндай билікке көтерілмеген. «Шыңғыс хан» Тэмужиннен бұрын да, одан кейін де ешкімге берілмеген, арнайы ойлап табылған атақ болды. Оның қайдан шыққаны туралы да дау-дамай, талас-тартыс көп. Бір кездері ол «теңізді» білдіретін «тенгиз» деген түркі сөзінен шыққан деген тұжырым кеңінен таралды, ал теңіз расында да тамсануға лайық болуы мүмкін. Тағы бір нұсқа - бұл атау «жұмақ» немесе «аспан» сөздерінің бұрмаланған түрі дегенді алға тартады, ал атақтың иесін «Көктің әмірімен» билік еткен қытай императорларымен бір дәрежеге қоятын «Тәңірі» деген сөз дейді. Соңғы пайымдама тоғызыншы немесе оныншы ғасырлардың руналық жазбаларынан табылған «Шыңғыс» сөзі түркі-моңғолша аралас «қатігез, берік, айбарлы» дегенді білдіреді, бұл оның иесіне әбден лайық. Содан кейін бұл сөз қолданыста қалды деседі. Ең сенімді дерек көзі де осы» (Мэн, 2010: 52). Ғалым бұл жерде әртүрлі пікірлерді сарапқа салады. Әлемге кең таралып кеткен «теңіз, мұхит» баламаларының да шындықтан алыс екені рас. Бұл сөз жоғарыда айтқанымыздай Шыңғыс ханға мінездеме берумен шектеледі, лауазымды ұғымды білдіре алмайды.

Жоғарыда аталған Джон Мэннің еңбегінде «Шыңғыс» сөзіне нұсқа ретінде «Тәңірі» терминін де алға тартып, «Шыңғыс» сөзі оның бұрмаланған түрі деген пікір жазған.

Осы жерде Шәді ақын өзінің дастанында Темужинді «Шыңғыс» деген атау Жаратушыдан келген аян еді, деп көрсетеді. Дастанда Көкше есімді болашақты болжайтын, Тәңірімен тілдесетін кейіпкер суреттеледі.

Бір күні халық алдына Көкше келді Аузымен бұл сөзді айтып хабар берді.

Ортадан Тамужинді хан қылыңыз,

Шыңғыс деп мұнан кейін айтыңыз Сіз.

Халықтың баршасына хабар беріп,

Алладан мәлім болды маған бұл сөз.

Дүниенің шаһлығының бәрін қәма,

Шыңғыстың әулетіне берді жана

Өзінің заманында ұрысқанмен

Тең бола білмес деді ешкім аңа.
Бұл жерде Шәді өзі діншіл ақын болғандықтан Тәңірі ұғымын Алла деп беріп отырған болуы керек. Осы жырда бейнеленген Көкше есімді кейіпкер туралы қазақ ғалымы У.Шәлекеновтің мынапікірі көңілгеқонады: Осы құрметті атақты Тэмужинге беру үшін оның төңірегіндегі ақыл айтатын зиялылар арнайы пікірлесіп, кеңесіп, ой елегінен өткеріп, онан кейін Тэмужиннің алдынан өтіп, оның ризалығын алғаннан кейін, Ұлы Кұрылтайда Моңғолдың сол кездегі ұлы шаманы Теб-Тенгриге (Кэкчу) Құдайының атынан жарияландырған», - деп жазады.Ғалым У.Шәлекеновтің келтіріп отырған дерегіндегі Кэкчу шаманы Шәдінің дастанындағы Көкше болса керек. Джон Мэнніңбіз жоғарыда келтірген «Тағы бір нұсқа - бұл атау «жұмақ» немесе «аспан» сөздерінің бұрмаланған түрі деген пікірдікелтіреді, ал атақтың иесін «Көктің әмірімен» билік еткен қытай императорларымен бір дәрежеге қоятын «Тәңірі» деген сөз» деген көзқарасынаШәдінің ойы да жақындайды.

Ал тарихшы ғалым У.Шәлекенов «Шыңғыс» сөзінің баламасы «Шығыс» деген түрік сөзінен шыққан. Ол сөз «Шығыстың ханы» (властелин Востока) деген мағына береді. Бұл кейін хатқа түсірерде «шығыс» сөзіндегі «ғ» әрпі «ң» әрпімен алмасып кетудің нәтижесінде алғашқы сөздің мәні өзгеріп кеткен. Олай болса, Тэмужинге берген лауазымды атақ сөзі «Шығыстың ханы» деген. Оның этимологиясы Шығысты билеуші (властелин Востока) деген мағынаға саяды. «Шыңғыс ханның» өзі де бұл атауды мойындаған»деп жазады (Шәлекенов, 2013). «Шыңғыс» атауы жайында жазушы Мұхтар Мағауин өзінің еңбегінде Рәшид-әд-Динге сілтеме жасай отырып, «Қазіргі қазақ тілінде «шың» - таудың ұшар басы, биік сеңгір. («Шың» сөзінің Рәшид-әл-Дин келтірген «берік, күшті» мағынасы «шыңдалу» етістігінің түбірінде сақталған: беркіну, күшею, шынығу). Сонымен қатар, «шың» - байырғы қазақ тілінде «темір», жай ғана емес, айрықша сапалы темір. Ескерусіз қалмас тағы бір жағдаят, дыбысталуы үйлес «шаң» - ең биік меже: шаңқан, шаңырақ, шаңқай түс; Ежелгі Ғұн патшалары «шаңғұй» (жаңғұй) атанған. Сонда жинақтап келгенде «Шыңғыс» атауының мағынасы - биік, берік, асқаралы, ұлұғ болып шығады». (Мағауин, 2013).«Шыңғыс» атауы қағанға берілген мәртебе емес, есім деп ұйғарсақ, онда жоғарыда келтірілген берік, биік, ұлық дегеннің барлығы да қисынға келеді. Әрине бұл мәселе төңірегінде түрлі пікірлерді сарапқа салдық, алайда нақты тұжырымды дәл айта ал- 
маймыз. Бұл мәселе әлі де зерттеуді қажет етеді.

Шәдінің дастанындағы Шыңғыс кейде әлемді жаулаушы диктатор ретінде берілсе, кейде әділдік жолымен де көзге түседі.

\footnotetext{
Шыңғыс хан өз күшімен шахлық еткен,

Уақытында онша түрлі іс көрсеткен.

Хорасан, Иран, Тұран, Дешті қыпшақ,

Үндістан, Қытайға шейін үкімі жеткен

(Жәңгірұлы,Қолжазба қоры: 75)
}

Дастанның «Шыңғыс ханның Мұһмадилуажды сұлтан Мұһаммад Хорезмға елші қылып жібергені» атты тарауда екі ел арасындағы қарым-қатынастың тарихын баяндайды. Ақын шығармада Сұлтан Мұһаммад Хорезм шахтың билік жүргізген аймағын былай суреттейді:

\footnotetext{
Айтылған Хорезм деп Хиуа ханы,

Айтылған Сұлтан Мұһаммад ердің нәмі (нәмі- есімі, аты)

Үкіміне бағын болып қарап тұрған,

Түркістан, Бұхара, Қоқан тамам бәрі.

Үндістан, Мәлак, Иран, Бағдатқаша

Шаһарлар мемлекеттер бар дүр онша.

Патшаның Сұлтан Мұһаммад үкіміне еніп,

Тұрарды бағын болып тамам барша
}

Ал дәл осы кезде Шыңғыс ханның қарамағына енген аймақтар жайлы былай дейді:

Шыңғыс хан Қытай, Мағұл бәрін алып,

Үкіміне татарлар һәм ырзаланып.

Патшасы Хорезмнің Мұһаммедке,

Ойланды сөйлеспекке елші салып

(Жәңгірұлы, Қолжазба қоры: 134)

Бұдан кейін екі мемлекет арасында достық қарым-қатынас орнату үшін Шыңғыс хан Хорезм шахқа елші жібергенін баяндайды. Жіберген елшіні Сұлтан Мұһаммед жақсы қарсы алып, халқының қамын ойлап ынтымақта болуды көздеп, елшіні құрметтеп шығарып салады. Осыдан бастап екі ел арасында сауда-саттық жақсы дамиды. Екі елдің арасындағы келісімге байланысты сауда жасау үшін Хорезм, Қоқан, Бұхара саудагерлері Шыңғыс ханның еліне келіп сауда жасап, жұмыстарын жүргізеді. Екі елдің саудасаттық қарым-қатынасының жақсарғанына қуанған Шыңғыс хан енді өз халқынан да сауда керуенін жіберуді ойлайды.

Бір бөлек әскер менен саудагерді,

Жолдас қып керуендермен жіберді оны.

Отырар деп ат қойылған бір шаһарға,

Мағұлдың адамының барды бәрі

(Жәңгірұлы,Қолжазба коры: 137).
Ол шаһарды басқаратын Қайырхан екенін, ол сұлтан Мұһаммедтің нағашы ағасы екені айтылады. Көптеген тарихи деректерде Шыңғыс ханның Отырарға шабуылды ұйымдастыруына себеп сол шаһардың ханы - Қайыр хан деп көрсетеді.

Дастанның желісі бойынша Қайырханның қабылдауында болған Шыңғыс ханның саудагерлерінің бірі Отырар ханның жасырын атын біліп, оны сол атымен шақырады. Осы жайға қаһарланған хан олардың бәрін қырып салады. Дастанда бұл оқиға былай беріледі:

Патшаның Қайыр біліп хабарын,

Керуеннің адамының қырды бәрін.

Бір барған сардарында өлтірісті,

Қазынаға алып келген салды малын.

Осы шараға қапаланған Шыңғыс хан Отырар деген әйгілі жорығын бастайды. Ежелден өзгермейтін заң, бұлжымайтын дәстүр болған, бір мемлекеттен келген елшіге зәбір көрсетпеу, өлтірмеу. Ал Сұлтан Мұхаммед Шыңғыс қағанның үшінші рет Отырардың билеушісі Қайырханды ұстап бер деген сөзіне қырын қарап, жіберген елшілерін өлім жазасына бұйырады. Осы жағдай Шыңғыс ханның Хорезмшахқа деген өшпенділігін күшейтіп, соғыс ашуға себепкер болды. Бұл пікірімізді ғалым В.В. Бартольд растайды: «Жойқын соғысқа дем берген Мұхаммед Сұлтанның байыбына бармай асығыс жасаған іс-әрекеті» - деп жазады ол өзінің еңбегінде (Бартольд, 1963: 476).

«... Что касается числа погибших, то по Джувейни, погиб весь караван (т.е. 450 человек), кроме одного человека (по Джузджани, он был погонщиком верблюдов), которому удалось спастись бегством и принести страшную весть Чингиз-хану. Чингиз-хан и тут обнаружил свою всегдашнюю сдержанность и самообладание (Бартольд, 1963: 466-467].

Ғалым В.В. Бартольд бұл пікірді бірнеше орта ғасырда өмір сүрген тарихшылардың пікіріне сүйене отырып растайды. Демек, Шәді ақын да осы деректерге сүйеніп отырған.

Дастанның «Үгдай хаһан, Шағатай ұрысып Отырарды алғаны» атты тарауында Шыңғыс ханның әскері Отырарды қалай жаулап алғаны туралы толық баяндалады. Шыңғыс хан өзінің ұлдары Үгедей мен Шағатайды әскерімен Отырарға атттандырады. Бірақ Сұлтан Мұһаммад Шыңғыс хан әскерінің келе жатқанын есітіп, Отырарды қорғау үшін елу мың әскерін жібереді. Қараша Һажаб есімді саркар өзінің 
он мың әскерімен Қайырханға келіп қосылады. Отырардың бекінісі мықты еді. Шағатайдың әскері бес айға дейін қалаға кіре алмай әуре болады.

Отырарға шаһзадалар келіп қонды,

Шаһарды алу үшін қадам қойды.

Қайырхан іште тұрып ұрыс қылды,

Ақыры бес айғаша амал қылды.

Бір күні Қараша һажаб Қайырханға бұлай қамалып отырғанымыз жарамайды. Халыққа қиын болды. Шаһзадалармен бітімге келіп, келісейік, - деп ұсыныс айтады. Қайырхан мұның ойын құптамайды, келіспейді. Мұны естіген Қара һажаб бітімгершілік жасауды ойланып, өзінің әскерімен Шағатайларға өзі келеді.

Шаһзаттар һажабқа айтты ойлап ізһар,

Өзіңе тұзын берген патшаһың бар.

Тұз-дәмін ішіп жүрген патшаһыңа,

Бұл түрлі бейофалық ойладың кәр.

Содан қаланың дарбазасын ашып, шаһардың халқын аяусыз қырады. Қайырханның әскерінің бәрі қырылып, ал өзін қолға түсіріп, шаһзадалардың алдына алып келіп,

«Көксарай» деген жерге алып барып,

Өлтірді қылышпенен басын алып, -

(Жәңгірұлы,Қолжазба қоры: 154).

деп жырлайды. Шәді ақын осы тарихи оқиғаны жазу барысында көптеген тарихи деректерді қарағаны аңғарылып тұр. Осы оқиғаны баяндау барысында ақын осы бейкүнә халықтың қанының төгілуіне Отырар билеушісі Қайырханның ойланбай жасаған әрекеті түрткі болды деген ойға жетелейді. Осы оқиғаға байланысты тарихшылардың пікірі де екіге жарылады. Біз тарихшы емеспіз, біздің мақсат әдебиеттегі Шыңғыс хан бейнесін ашу. Бірақ көркем әдебиетте де осы қарама-қайшылықты көзқарасты білдіретін шығармалар бар және ол шығарма халықтың арасына кең тараған.

Мәселен Шыңғыс ханның Отырарға жорығы жайлы баяндалатын Мұхтар Шахановтың «Жеңілген жеңімпаз хақындағы Отырар дастаны немесе Шыңғысханның қателігі» поэмасында оқиға басқа қырынан сипатталады.(Шаханов, 2003).

Тарихи деректерге сүйенсек, бес ай бойы Шағатай әскері Отырарға кіре алмайды. Бұл жайында В.В. Бартольд: «По Джувейни, Отрар защищался пять месяцев, цитадель - еще один месяцев», - деп жазады (Бартольд, 1963: 466467).

Шәдінің «Тарихнама» дастанында да да бес ай бойы әскердің қамалдан кіре алмағаны айтылады. Сондай-ақ, моңғолдар Отырардың халқын жауыздықпен қырғанын суреттейді. Шығармада осы соғыстан қарапайым халық көп зардеп шеккенін, аяусыз қырылғаны баяндалады. Шәдінің «Тарихама» дастанында осы соғыстың тууына бірден-бір себепкер Отырардың басшысы Қайырханның ашкөздігі және істің ақ-қарасын ажыратпай Қайырханға қолдау көрсеткен Сұлтан Мұһаммадтың ойсыз жасаған әрекеті деген ойды аңғартады. XX ғасыр басында дүниеге келген бұл шығармада Шәді ақын Отырардың күйреуінің түпкі себебі туралы өзіндік ойын анық көрсетеді.

Кез келген ақын - жазушы өткен тарихи оқиғаларды өз шығармасына арқау етсе де, ол негізінен сол қаламгер өмір сүрген кезеңдегі танымның жемісі. Өзі өмір сүріп отырған кезеңнен әлдеқайда ерте кезеңді тілге тиек етсе де, ол автор өмір сүрген күннің көзқарасымен пайымдайды. Өткен күннің ескісін жаңартып, оқырманға бейтаныс боп келген тағы бір қырын, бір ақиқатын бүгінгі пікірмен жаңаша қырынан танытуға тырысатынын біз жоғарыда айтқанбыз. Сондықтан М.Шаханов өзінің шығармасында Шыңғыс ханның тарихи бейнесін бейнелеу үшін қазақ жеріне, тарихына қатысты кезеңіне ғана тоқталып, өзінше байлам жасағанжәне өзінің авторлық ұстанымын ашық көрсете білген. М.Шахановтың ақын болып қалыптасқан кезі Кеңес одағы дәуіріне туракелді. Кеңес кезеңіндегі жазылған тарихи еңбектерде Шыңғыс хан тек негативті тұлға ретінде танылғаны бүгінгі күні баршаға аян. Шәді Жәңгірұлының «Тарихнама» дастанында Шыңғыс ханмен оның ұлдарының әйгілі ірі-ірі жорықтары өз кезегімен суреттеледі. Сонымен бірге Шыңғыс қағанның өзінің жаулап алған жерлердегі халықтардың дініне, дәстүріне тимегені айтылады. Әсіресе ислам дінін қатты құрметтегені байқалады.

Шыңғыс қағанның ел қамын ойлап, өзі құрған патшалықтың іргесі шайқалмауы үшін балаларына әрқашанда бірлікте болыңдар, - дейді.

\footnotetext{
Менен соң біреуіңізді патша қылып,

Үкіміне тұрсаңыздар мойын ұсынып.

Сіздерге ешкім дұшпан бола алмағай,

Тұрады қол астыңа бәрі кіріп,

(Жәңгірұлы,Қолжазба қоры, 131).
} 
Шәді бұл поэманы ұзақ уақытүлкен ізденіспен жазған. Ол әрбір тарихи оқиғаларға ерекше мән беріп, мұқият қарап, содан өзінше түйін шығарып отырады. Ақын поэмада тек тарихи деректерді ғана емес, халық арасында кең тараған аңыз-әңгімелерді де өз ретімен қолдана білген деп жоғарыда айттық. Ақын шығармада Шыңғыс ханның тұңғышы Жошының қайғылы өлімін ханға естіртуі жайлы аңыз әңгімелерді асқан шеберлікпен жырлайды.

Шыңғыс хан өзінің дүниеден өтетінін түсінде көріп біледі. Өзінің артына мұрагері ретінде таққа үшінші ұлы Үгдай қағанды хан сайлайды. Шыңғыстанушы 3. Қинаятұлы өзінің еңбегінде: «Шыңғыс хан демі үзілер шағында қасына ұлдары Өгедей мен Тулуй екеуін шақыртып: «Менің өлетін шағым болды. Тәңірдің қуатымен сендерге ұлы мемлекет құрып бердім, Мемлекеттің бір шетінен екінші шетіне дейін бір жылдық жол. Сендер құрып берген елімді бытыратпау үшін жауларыңа бір кісідей бірлесе жүріп соққы беріп, достарыңа рақымшылықпен қараңдар. Ұлы тақты біреуің ғана жалғаңдар. Бұрын айтқанымыздай, ол мұрагер Өгедей», (Қинаятұлы, 2008: 372) - деп жазады.

Отырған үшбу ұғлым Үгдай қаһан,

Хан қылып отырғыздым орныма мен.

Жан-ділмен өзгелерің тілін алып,

Тұрыңыз айтқан әмірі бірлән.

Осылай адамзат тарихындағы аса ірі тұлғаның бірі Есукейұлы Темужин өмірден өтеді.

Дастанда Шәді Шыңғыс ханның портретін былай береді:

Таза еді денесінің тамам бәрі,

Өзгеден көкірегі кең, зор кеудесі.

Жүзінде айбаты бар, маңдайы кең,

Көрмекке ұзын болған сақалдары.
Ақын оның өте қайратты, жігерлі болғандығын, ұрыс алаңында өзі алдыңғы сапта тұратынын, өзінің көңілі сенбей біреудің дегеніне ермейтінін, ашуының қайтымы тез екенін, барған жерінде әуелі бітімге келуді сұрайтынын, оған көнбегенді шауып алатынын, ғалым мен өнерліні өлтірмейтінін, оларды өз халқына апарып өнерін үйренетінін жырға қосады.

\footnotetext{
Өзгеден артық болып сақылығы, Алдынан кетпес еді ешкім құры, деп, оның мәрттігін жырласа,

Өз дінін өзгертпестен тұтып жүрді,

Артықша ислам дінін құрмет қылды.

Жанында жақын болған адамдардың,

Көбісі мұсылман деп айтып жүрді

(Жәңгірұлы,Қолжазба қоры: 249)
}

деп, оның ислам дініне сенгенін айтады.

\section{Қорытынды}

«Тарих-нама» ішіндегі тарихи деректері тұрғысынан да, мазмұны мен көркемдігі жағынан да құнды шығарма. Поэмада ақын өзінің бұл еңбекті жазудағы негізгі мақсаты-өшіп бара жатқан хан тарихын қайта жаңғырту, өткен тарихпен оқырманды таныстыру. Өзі де төре ұрпағы болғандықтан ақын бабаларының ұмыт болып бара жатқан тарихын өзі жырламағанда кім жырламақ деп, мұны жырлау өзіне перзенттік парыз деп біліп, өзін-өзі қайрап, содан күш қуат алғандай болады.

Қорыта айтқанда, қазақ әдебиетінің қай жанрында болмасын Шыңғыс хан жайлы, оның бейнесі туралы кездестірмей қалмайсыз. Бұл, біздің әдебиет пен тарихтың тығыз байланысты екенін және бірге жасай беретіндігін дәлелдесе керек.

\section{Әдебиеттер}

Назарбаев Н.Ә. Ұлы даланың жеті қыры // Егемен Қазақстан. 21.11.2018

Әбдезұлы Қ. Тарих және тағдыр. - Алматы: Қазығұрт, 2004. - 208 б.

Келімбетов Н. Шәді ақын. - Алматы: Жазушы, 1974. - 96 б.

Әдебиет және өнер институты Қолжазба қоры. 888 бума. 1 - дәптер.

Жәңгірұлы Шәді. Тарих-нама. Әдебиет және өнер институты. Қолжазба қоры. 888 бума.

Қазақстан: Ұлттық энциклопедия / Бас редактор Ә. Нысанбаев - Алматы, 1998, VIII том.

Моңғолдың құпия шежіресі: XII-XIII ғасырлардағы көшпелілер шежіресі. - Алматы: Өнер, 2009. - 216 б.

Хара-Даван Э. Чингис-хан как полководец и его наследие. Культурно-исторический очерк Монгольской империи ХІІ-

XIV века. - Элиста, Калмыцкое книжная издательство. 1991.

Әбенайұлы Т. «Құпия шежіренің құпиясы. - Алматы: Нұрлы әлем, 2016. - 576 б.

Мэн Д. Шыңғыс ханның көшбасшылық құпиясы, - Алматы:Аспандау, 2010. - 216 б.

Шәлекенов У. «Шыңғыс» сөзі қайдан шыққан?, Ана тілі газеті. 6 маусым, 2013. http://anatili.kazgazeta.kz/?p=14412 
Мағауин М. Шыңғыс ханжәне оның заманы. Алматы, Дәуір. 2013. - 580 б.

Бартольд В.В. Туркестан в эпоху монгольского нашествия. - М., 1963. - Т. 1. - С. 760.

Шаханов М. Эверестке шығу. - Алматы: Атамұра, 2003. - 272 б.

Қинаятұлы 3. Шыңғыс хан // Бірінші кітап. - Алматы: Арда, 2008. - 4326.

\section{References}

Ábdezuly Q. (2004). Tarıhjánetaǵdyr. [History and Fate]. Almaty, Qazyǵurt, 208 b. (In Kazakh)

Ábenaiuly T. (2016). Qupıashejirenińqupıasy. [The secrets of the secret cronicles]. Almaty, Nurly álem, 576 b. (In Kazakh)

Ádebiet jáne óner institýty Qoljazba qory. [Institute of Art and Literature. Manuscript. 888 papers]. 888 býma. 1 - dápter.

BartoldV.V.(1963). Týrkestan v epohýmongolskogonashestvı1a. [Turkestan during the Mongol Conquests], Moskva, T. 1. 760 s.(In Russian)

Hara-Davan E. (1991). Chıngıs-hankakpolkovodets1 ego nasledıe. Kýltýrno-1storıchesk11ocherkMongolsko1ımperı1 XII-XIV veka.[Chinggis Khan as military leader and his legacy. Culture - historical essay on the Mongol Empire of the $12^{\text {th }}-14^{\text {th }} \mathrm{cc}$.]. Elista, Kalmytskoeknijnaiaizdatelstvo, 196 s. (InRussian)

Kelimbetov N. (1974).Shádiaqyn. [The poet Shadi]. Almaty, Jazýshy. 1974. 96 b.(In Kazakh)

Jáńgiruly Shádi. Tarıh-nama. Ádebietjáneónerınstıtýty. Qoljazbaqory. 888býma.

Man J. (2010). Shyńǵyshannyńkóshbasshylyqqupılasy, [The Leadership secrets of Genghis Khan]. Aspandaý, 216 b.(In Kazakh) Maǵaýın M. (2013). Shyńǵys Khan jáne onyń zamany. [Genghis Khan and his era]. Almaty, Dáýir. -580 b.(In Kazakh)

Mońǵoldyńqupıashejiresi: XII-XIII ǵasyrlardaǵykóshpelilershejiresi.(2009). [The Secret History of the Mongols]. Almaty: Óner, 216 b.(In Kazakh)

Nazarbayev N. (21.11.2018). Ulydalanyńjetiqyry. ["Seven Facets of the Great Steppe"] EgemenQazaqstan.

Qazaqstan: Ulttyq entsıklopedı1a (1998), [Kazakhstan: National Encyclopedia], Almaty, VIII tom.(In Kazakh)

Qinayatuly Z. (2008). Shyńǵyshan. [Chinggis Khan]. Almaty: Arda. 372b.(In Kazakh)

Shálekenov Ý.(2013). «Shyńǵys» sóziqardanshyqqan?,[What is the origin of the word “Chingiz”?] Ana tiligazeti. 6maýsym,http:// anatili.kazgazeta.kz/?p=14412 (In Kazakh)

Shahanov M. (2003). Everestkeshyǵý. [Climbing Everest]. Almaty, Atamura. 2003. 272 b. (In Kazakh) 